\title{
Tumuli u Dalmaciji - posljednjih 2000 godina
}

Jure Šućur

DOI: $10.17234 / 9789531757232-08$

Uvod

Arheološka se nalazišta obično kriju ispod površine zemlje, no postoje i ona koja su lako uočljiva i prisutna u krajoliku od samog trenutka nastanka, bez obzira koliko se taj trenutak nalazio daleko u prošlosti. Piramide u Gizi samo su jedan od poznatijih primjera koji već više od 4500 godina svjedoči povijesnim mijenama uz Nil. Dioklecijanov mauzolej pretvoren u katedralu sv. Dujma jedan je od bližih primjera - svjedok brojnih promjena Splita tijekom posljednjih 1700 godina. Oba su primjera ujedno i grobnice i nadgrobni spomenici. Slično je i s brojnim tumulima koji se kao oblik sahranjivanja pokojnika javljaju u brojnim kulturama u različitim vremenima i na gotovo svim kontinentima.

Tumuli (humci, gomile, gromile) zapravo su najstarija sigurna vanjska obilježja grobova. To su stožasti humci izgrađeni od različitog materijala, ovisno o raspoloživosti na mjestu podizanja, a podignuti su kako bi bili trajno i (nadaleko) vidljivo obilježje groba pojedinca ili većeg broja članova zajednice. Najstariji tumuli podignuti su u mlađem neolitiku u Sjevernoj i Zapadnoj Europi te eneolitičkim kulturama istočne Europe. U srednjoj se Europi ovaj način pokopa uobičajio tijekom ranog i srednjeg brončanog doba. U Podunavlju i na Balkanu njihova se pojava veže uz prodor novih naroda s istoka tijekom eneolita (Srejović 1997: 1067 -1068). Na tom se prostoru intenzivno koriste kroz brončano i starije željezno doba, a kroz mlađe željezno doba postupno nestaju.

\section{Povijest istraživanja}

U Dalmaciji su tumuli, posebno oni kameni, izrazito uočljiv element pejzaža pa su ih ljudi prepoznavali kao ostatke prošlih ljudskih djelovanja (sl. 1). Oni su kao takvi privlačili pažnju i prije razvoja arheologije kao znanosti. 0 tome svjedoče zapisi koji su nam očuvani u djelu Cronica dell' isola della Brazza Andrije Ciccarellija iz 1802. godine, koji pak prenosi podatke bračkog kroničara Vicka Prodića (1628.-1663.) kako su neki pojedinci prekapali tumule u potrazi za srebrom i zlatom (Jutronić 1955: 364).

Brojne su se legende i predaje vezivale i još danas se vezuju uz tumule. Tako se uz tumul Velika Crljivica u Imotskoj krajini vezuje predaja kako se pod kamenom krije crkva koju je narod zajedno s crkvenim ruhom, kaležima i zvonom zatrpao kamenom kad se povlačio pred osman- 
lijskim osvajanjima (sl. 2). Upravo se to zvono navodno čuje noću od blagdana Duhova do Sv. Ante, a tko bi dirao u tumul obolio bi i izazvao tuču koja bi uništila usjeve (Dragun \& Ujević 2014: 20).

Početke istraživanja tumula možemo vezati uz početke razvoja arheologije kao znanosti u 19. st. Godine 1861. Grgur Bučić i Petar Boglić istraživali su tumule u blizini grada Hvara, i o tome se pisalo u više radova (Boglić 1873: 7-8; Bucchich 1885: 6-9). Ova se istraživanja smatraju prvim arheološkim istraživanjima prapovijesnih lokaliteta na tlu Hrvatske (Batović 1963: 42; Petrić 1975: 244), ali se čini kako je Bučić s Jerolimom Machiedom počeo istraživati hvarske tumule još 1850-ih, no ta istraživanja nisu objavljena iako su nalazi završili u Machiedovoj zbirci (Weiser 1884: [8]-[9]; Novak 1924: 16; Petrić 1977: 222). Niz istraživanja tumula nastavlja Vid Vuletić-Vukasović na Braču (Vuletić Vukasović 1885a: [50]), koji uočava i pojavu kamika (stećaka) ${ }^{1}$ u kontekstu tumula u Hercegovini (Vuletić Vukasović 1885b). Slijede Ivan KrstiteljNovak, Frane Bulić, Josef Szombathy, W. Buttler, E. Dyggve i fra Lujo Marun koji je uočio naknadne ukope u prapovijesne tumule, a za neke dvojio jesu li uopće u pitanju prapovijesni tumuli (Šućur 2015a: 28-36).

Istraživanja tumula nastavila su se nakon Drugoga svjetskog rata, a istraživači su bili svjesni i njihovih kasnijih vremenskih horizonata ukapanja. Posebno su važna istraživanja Janka Beloševića, a dijelom i I. Marovića. Malo-pomalo naša su se saznanja o ponovnom korištenju tumula obogaćivala novim istraživanjima, a iznimno su vrijedni rezultati zaštitnih istraživanja izvedenih prilikom gradnje Jadranske autoceste na prostoru između Krke i Neretve, kao i istraživanja Odjela za arheologiju Sveučilišta u Zadru na prostoru sjeverne Dalmacije. S tim se istraživanjima prestalo tumule gledati isključivo kao prapovijesne spomenike te su nalazi i grobovi koji su ukazivali na antiku, srednji i novi vijek obrađeni s jednakom pažnjom kao i oni prapovijesni.

Naknadni, sekundarni ukopi u već podignute tumule događali su se još tijekom prapovijesti, a naknadne ukope bilježimo i u prvim stoljećima povijesnoga doba, u ranoj antici. Na padinama brda Kamenica s desne strane delte Neretve istražen je tumul Torine - Tumul 20, gdje je uz primarni prapovijesni grob, na rubu tumula ukopano i šest zidanih ovalnih grobnica po rubu tumula u kojima je pokopano po više pokojnika, zajedno s mnoštvom nalaza koji upućuju na mlađe željezno doba (Šućur 2015b: 567-568). Primjer ranih povijesnih ukopa pruža nam Tumul 14 na lokalitetu Šparevine u gornjem toku Cetine gdje je, uz brončanodobni i dva srednjovjekovna groba, istraženo 47 paljevinskih grobova koji su datirani u 1. st. i u prvu polovinu 2. st. (Marović 1963: 21-64). Prema sadašnjem stanju istraživanja nakon tog vremenskog horizonta nastaje kratki hijatus kod ukapanja u dalmatinske tumule, te se sekundarni ukopi ponovno javljaju u kasnoj antici (Šućur 2015a: 7), a ti su se ukopi nastavili i kroz srednji i kroz novi vijek.

\section{Općenito o ukapanju u tumule u Europi od antike do novog vijeka}

Naknadni ukopi u tumule, naravno, nisu fenomen koji se javlja samo u Dalmaciji. Sekundarni ukopi različitog karaktera nalaze se u tumulima diljem Europe. Od antike do novog vijeka najčešći su ukopi iz ranog srednjeg vijeka što nije neobično s obzirom na to da se tada na cijelom prostoru Europe podižu mnogobrojni tumuli. Jedan od uobičajenih slavenskih pogrebnih ritusa uključuje gradnju tumula nad incineracijskim ili inhumacijskim grobovima (Niederle 1954: 65-94; Měřínský 2009: 101-114). Većina tumula na prostoru Češke i duž središnjeg Dunava je datirana od sredine 8. do početka 11. st., dok ih je samo nekoliko ranijih, a pojedini uz obalu Baltika se mogu datirati do 12. st. Dalje se prema istoku bez prekida nastavlja prostor s isto-

\footnotetext{
${ }^{1}$ Iako je naziv stećci kao termin za specifične nadgrobne spomenike uobičajen u arheološkoj literaturi, a ponekad se njime krivo nazivaju i nadgrobne ploče, u tekstu koristim termin kamici (jednina: kamik) u skladu s argumentacijom Krešimira Kužića (Kužić 2001: 263-264).
} 


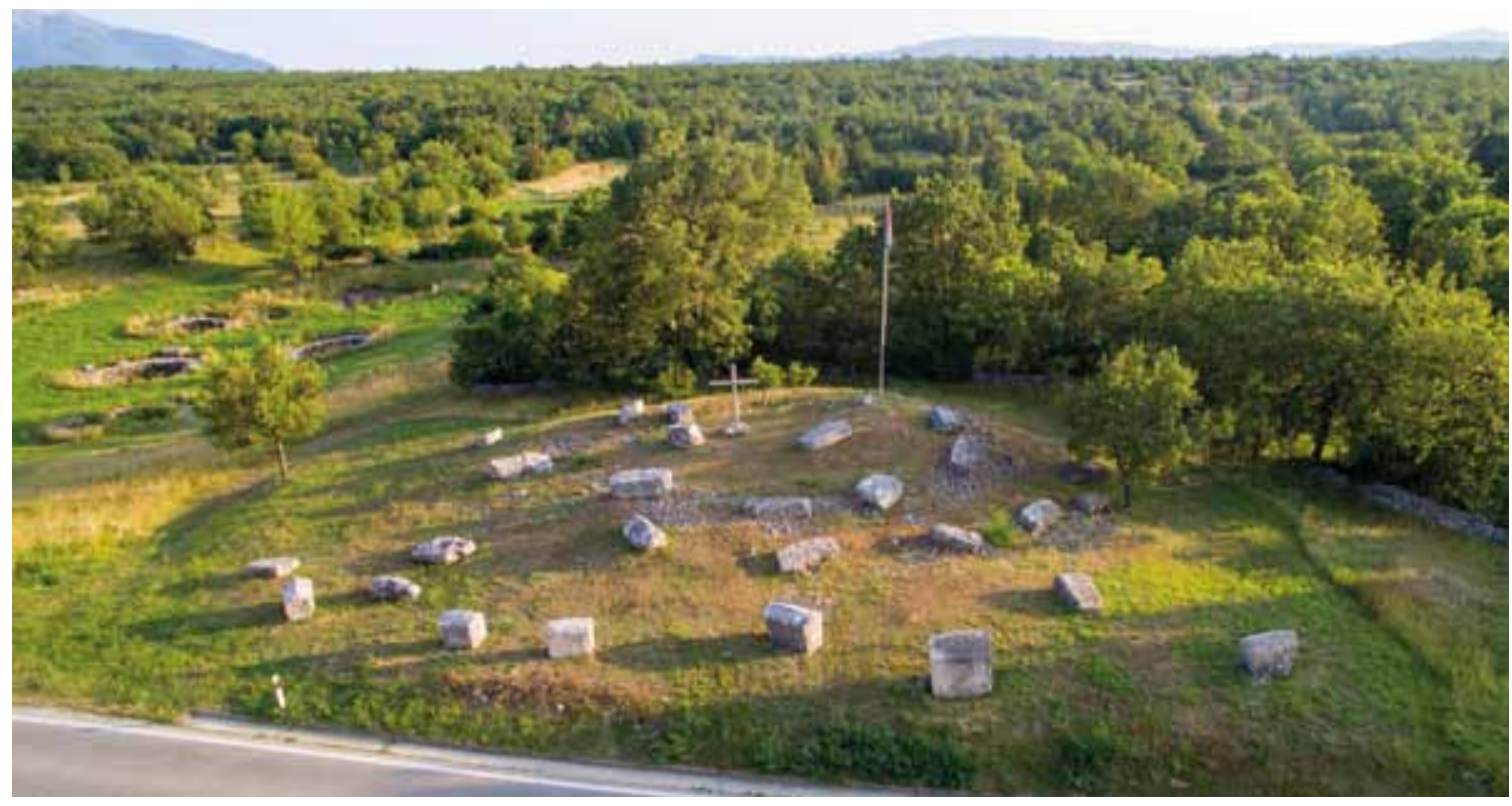

vremenim tumulima koji se vezuju uz razne nomadske narode, na koje se nadovezuju oni sibirski, s istočne strane Urala (Lutovský 1989; 1990; 1996). Ranosrednjovjekovni tumuli nalaze se i na prostoru koji nisu naselili Slaveni - u zapadnoj Europi, uključujući i Veliku Britaniju. Zapadnoeuropski tumuli su raniji, datirani od sredine 6. do sredine 8. st., i vezani su uz Germane, ali vidljive su i druge razlike (Van de Noort 1993: 67-69; Lutovský 1996). Ovdje je riječ o novopodignutim tumulima, ali postoje razlike i kada je riječ o ukopima u postojeće tumule. M. Lutovský navodi kako se u anglo-saksonskom svijetu podizanje tumula možda razvilo upravo iz ponovnog korištenja prapovijesnih, dok M. Carver vezano uz poznati anglo-saksonski lokalitet Sutton Hoo smatra kako je kod ukapanja u već postojeće tumule riječ o simboličnoj okupaciji novog prostora (Carver 1998). Na prostoru slavenskih tumula sekundarno ukapanje je rijetko, ali su takvi ukopi u prapovijesne tumule zabilježeni. Zanimljivi su primjeri iz Češke gdje podizanje novih tumula prestaje sredinom 10. st., a u pojedinim prapovijesnim zabilježeni su ukopi koji se datiraju u 11. i 12. st. (Hejhal \& Lutovský 2012). Ti bi ukopi mogli svjedočiti o dijelu zajednice koja je sporije prihvaćala kršćanstvo.

Grobovi iz kasnijeg vremena puno su rjeđi u odnosu na ranosrednjovjekovne, no postoje. Uvijek se radi o sekundarnim ukopima u starije tumule. Tako su u Srbiji, na prostoru Čačka, na šest lokaliteta u prapovijesnim tumulima zabilježeni grobovi datirani od 12. do 18. st. (Veseličić 2008). U prapovijesnim tumulima u Apolloniji u Albaniji pronađeni su i grobovi 17.-19. st. ukopani u površinu ili na rub tumula (Amore 2009: 181).

Posebno su zanimljiv primjer brojni prapovijesni tumuli na prostoru južne Nizozemske koji su u kasnome srednjem i ranome novom vijeku korišteni kao mjesta na kojima se vršilo pogubljenje osuđenih na smrt, bilo vješanjem ili na neki drugi način, te kao mjesta na kojima su izlagana njihova tijela. Primjer je skupina tumula Zevenbergen južno od Berghema gdje su na tumulu 2 pronađena tri „groba“, odnosno grobne jame s neuobičajeno položenim ostacima pokojnika, ali i velika pravilna okrugla jama na tjemenu tumula u kojoj je vjerojatno bio postavljen stup vješala. Ovakvo tretiranje tumula od 14. pa sve do kraja 18. st. potvrđuju i povijesni izvori (Meurkens 2010).

Ovo su primjeri koji svjedoče kako ukopi u tumule nisu ograničeni ni vremenski ni prostorno, a njihova pojava može imati različite uzroke i značenja. 

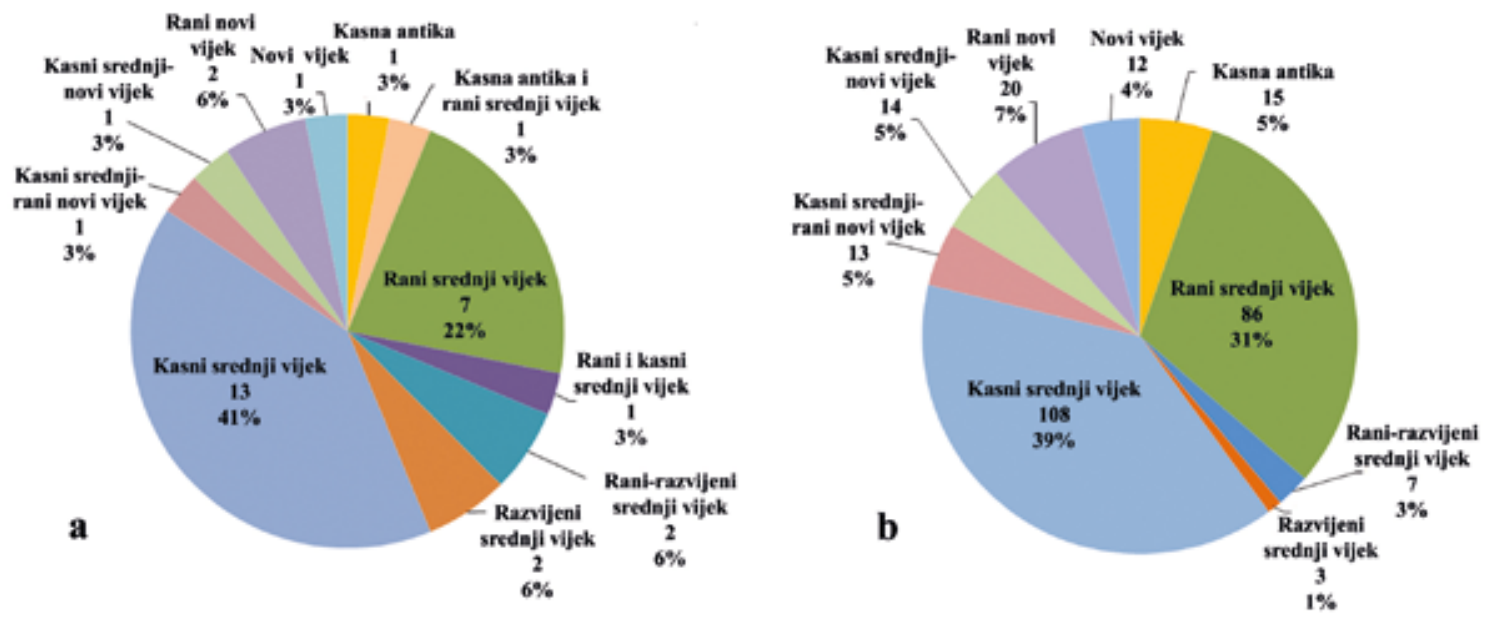

Tumuli kao mjesta naknadnih ukopa u Dalmaciji

U nastavku teksta bit će iznesena pojedina zapažanja o ukopima u Dalmaciji po pojedinim razdobljima, a izdvojit će se pojedini zanimljivi lokaliteti koji oslikavaju korištenje već postojećih tumula za ukope u kasnijim vremenima. ${ }^{2}$

Sigurne zaključke o naknadnim ukopima možemo temeljiti samo na potpuno istraženim tumulima, a koliko su naknadni ukopi česti može se reći samo za prostore gdje je istražen veći broj tumula. Na prostoru oko izvora rijeke Cetine I. Marović je između 1953. i 1973. godine istražio 130 tumula, a ukopi datirani od antike do novoga vijeka zabilježeni su na njih 14, što čini $11 \%$ tumula (Marović 1963: 37-172). Pogledamo li istražene tumule na prostoru Imotske i Vrgorske krajine udio tumula s grobovima iz posljednja dva tisućljeća penje se na $63 \%$, a na brdovitom prostoru Pline u zaleđu Ploča udio raste na 70\% (Šućur 2015a: 157). Iako se ovdje zajedno razmatraju svi vremenski horizonti, podaci svjedoče o regionalnim razlikama koje nisu posljedica vidljivosti samih tumula u pejzažu već duhovnih aspekata populacije koja je obitavala na pojedinom prostoru.

Proučavajući ovu tematiku na ukupno 75 tumula na prostoru između Zrmanje i Neretve bilo je moguće izvršiti uže datiranje grobova na 32 tumula (sl. 3a). Pojava naknadnih ukopa najizraženija je u kasnome srednjem vijeku (ukupno na 47\% tumula), a slijedi rani srednji vijek (28\%), zatim rani novi vijek, razvijeni srednji vijek te grobovi iz vremena kasne antike (po 6\%). Ostali tumuli imaju grobove koji pripadaju prijelaznim razdobljima.

Ako umjesto broja tumula razmotrimo grobne cjeline omjeri se mijenjaju, ali redoslijed ostaje gotovo isti (sl. 3b). Najbrojniji su kasnosrednjovjekovni grobovi (39\%), a zatim oni iz ranoga srednjeg vijeka (31\%). Slijede grobovi iz ranoga novog vijeka (7\%) pa grobovi korišteni i u kasnome srednjem i ranome novom vijeku, u kasnome srednjem i novome vijeku te u kasnoj antici (po 5\%). Najmanje su brojni novovjekovni grobovi te oni iz razvijenog srednjeg vijeka.

\footnotetext{
${ }^{2}$ Zapažanja se temelje na 75 potpuno istraženih tumula sa 428 grobova (ukupno 508) obrađenih u doktorskoj disertaciji (Šućur 2015a: 159). Prilikom rada na doktorskoj disertaciji zadužio me velik broj ljudi kojima bih stoga i na ovom mjestu želio zahvaliti, a poimence su navedeni u samom radu (Šućur 2015a: II-V).
} 
SI. 4: Pogled na tumul Škornica tijekom istraživanja s kasnoantičkim grobovima u prvom planu (fotografirao: D. Vujević 2006.).

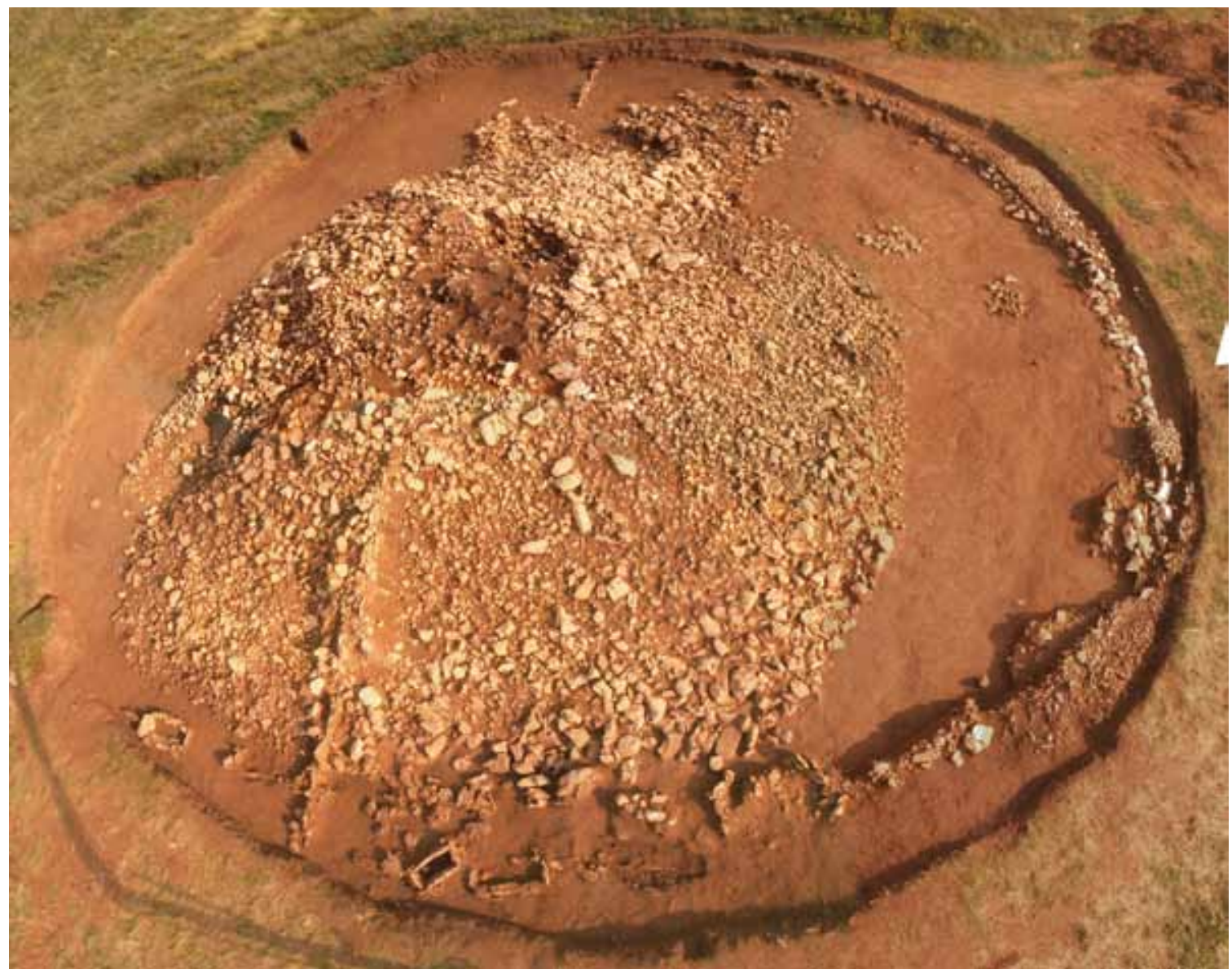

Omjer dviju najbrojnijih kategorija ukazuje kako se ranosrednjovjekovni grobovi javljaju na manjem broju tumula, ali su tada brojniji u odnosu na kasnosrednjovjekovne (Šućur 2015a: 158-160).

Ukopi u tumule u kasnoj antici zabilježeni su u Dalmaciji na tri tumula na prostoru Ravnih kotara. Tumul Škornicu u Privlaci (sl. 4) i Matakovu glavicu u Podvršju istražio je Odjel za arheologiju Sveučilišta u Zadru 2006. i 2008. godine.

$\mathrm{Na}$ Škornici je istraženo 11 grobova, ${ }^{3}$ koji se prema nalazu srebrne fibule u obliku ptice i željezne pređice s ravno odsječenom bazom trna datiraju u 5. i prvu polovinu 6. st. (Vinski 1991: 12; Fabijanić 2008: 269). Svi grobovi, osim jednog, pripadaju djeci, a arhitektura im je različita i prevladava korištenje kamena i kamenih ploča bez upotrebe žbuke. Na Matakovoj glavici zabilježena su četiri kasnoantička groba, vrlo raznorodne arhitekture, a od pokojnika se zbog kiselosti tla očuvala samo jedna lubanja u grobu 3. Na ovome je tumulu zabilježen i ranosrednjovjekovni horizont ukopa od kojeg su se loše očuvali ostaci arhitekture jednog groba, vatrište i pokretni nalazi keramike, brus i pređica koji ukazuju na 8. i prvu polovinu 9. st. (Gusar \& Vujević 2012).

\footnotetext{
${ }^{3}$ Iako je pri istraživanju definirano ukupno 14 grobova, od kojih 13 predstavljaju naknadne ukope, s obzirom na stanje očuvanosti držim kako se sa sigurnošću moguće govoriti samo o 11 grobova. Naravno, prvotni broj grobova je vjerojatno bio veći, ali oni su uništeni jer su bili ukopani u površinski sloj ili uz rub tumula (Šućur 2015b: 6-20).
} 
Upravo zbog više vremenskih horizonata ukapanja najzanimljiviji je lokalitet Kašić - Glavčurak. Radi se o velikoj nekropoli kod koje je dio grobova bio ukopan u tumul na južnom dijelu nekropole. Ukupno se uspjelo istražiti 25 grobova, od čega je 15 bilo na tumulu ili pored njega. Uz grobove iz vremena seobe naroda, odnosno prve polovine 6. st., zabilježena su i dva ranosrednjovjekovna horizonta ukopa - raniji grobovi bez kamene arhitekture (druga pol. 8. i prva pol. 9. st.), a u stratigrafski višem sloju grobovi s različitom arhitekturom od kamenih ploča (od 9. do 11. st.) no mnogi podaci koji su mogli rasvijetliti turbulentno razdoblje prijelaza iz kasne antike u rani srednji vijek izgubljeni su jer je nekropola najvećim dijelom uništena eksploatacijom pijeska (Belošević 1968).

Za razliku od kasne antike, ranosrednjovjekovni ukopi u tumule su česti i javljaju se na cijelom prostoru između Zrmanje i Neretve. U sjevernoj Dalmaciji ovaj horizont zabilježen je na tumulima Jokina, Matakova i Duševića glavica, te na lokalitetu Nin - Materiza, kod izvora Cetine to je tumul 22 na Rudinama, u zaleđu Splita lokalitet Konjsko polje - Ledine, u Poljicima Tugare - Donji Vrtal, a na vrgorskom prostoru dva tumula u Kozici i tri na Torinama u selu Dragljane (Šućur 2015a: 165).

Upravo je ukopima u tumule u ranome srednjem vijeku u hrvatskoj arheologiji posvećeno najviše pažnje. Naime, postavljalo se pitanje jesu li Slaveni po dolasku na istočni Jadran podizali tumule kao što su to činili u drugim dijelovima Europe ili su se samo koristili već postojećim tumulima (Belošević 1980: 70-71; Petrinec 2009: 103-104). S obzirom na to da su kod svih istraženih tumula pronađeni prapovijesni ukopi i/ili nalazi, može se zaključiti kako dosadašnja istraživanja nisu dala argumente za tvrdnju kako su Slaveni podizali tumule za ukapanje, ali možda buduća istraživanja promijene ovu tvrdnju (Šućur 2015a: 183).

Ranosrednjovjekovni grobovi u tumulima uklapaju se u opću sliku istodobnih nekropola, ali nam daju građu za razmatranje pojedinih pitanja. Posebno su zanimljivi tumuli s više ranosrednjovjekovnih horizonata: već spomenuti tumul Kašić - Glavčurak te Krneza - Jokina glavica i Kozica - Tumul 2. Tako je na tumulu Jokina glavica raniji horizont datiran u 8. i prvu polovinu 9. st., a kasniji u 9. st. (sl. 5). Na tumulu 2 u Kozici raniji je horizont datiran u 9. i 10. st., a kasniji u 10. i prvu polovinu 11. st. (Šućur 2015a: 165-166). Kod oba tumula razlika u horizontima vidljiva je u arhitekturi grobova i njihovim stratigrafskim odnosima. Upravo razlika u arhitekturi pokazuje kako pri gradnji nije igrao ulogu samo raspoloživi materijal, već i običaji. Dakle, iako je riječ o pogrebnim običajima koji su u pravilu podložni sporim promjenama, primjeri s tumula 2 kao i dvaju grobova 28 i 29-30-31 na tumulu u Konjskom polju ${ }^{4}$ svjedoče i kako je do te promjene došlo u relativno kratkom vremenu. Nedostatak nalaza u mlađim horizontima ne omogućava nam analizu mogu li se te promjene povezivati s prihvaćanjem kršćanstva, ali datiranje grobova sugerira takvu mogućnost. Naime, na Glavčurku i Jokinoj glavici promjena se događa u 9. st., kao i u Konjskom polju, dok se na tumulu 2 u Kozici dva horizonta preklapaju u 10. st., što odgovara kasnijem prihvaćanju kršćanstva na prostoru Paganije.

Ukopi iz razvijenoga srednjeg vijeka još su rjeđi od onih kasnoantičkih. Riječ je o četiri tumula čiji su grobovi datirani radiokarbonskom analizom osteoloških ostataka. Grobovi iz tumula 1 i 2 na lokalitetu Torine u Dragljanima kod Vrgorca datiraju se u kraj ranog i početak razvijenoga srednjeg vijeka, odnosno od 9. do 12. st. Grob istražen na Gomili u Kovačevićima u Gornjim Rašćanima datiran je u razdoblje 1160.-1280. godine, a dva groba iz Tumula 4 u Eracima u drugu polovinu 13. st. (Šućur 2015a: 184-186).

Najveći broj naknadnih ukopa u tumulima može se datirati u kasni srednji vijek, a oni se nalaze na cijelom razmatranom prostoru, od lokaliteta Sv. Grgur kod Nina do Mišje drage na desnoj obali delte Neretve, ali su najčešći na prostoru srednje Dalmacije. Potpuno istraženim tumuli-

\footnotetext{
${ }^{4}$ Radi se o grobu 28 i grobu 29-30-31 koji je objavljen kao tri groba, ali držim kako je riječ o devastiranom ukopu. Oni, za razliku od ostalih, imaju kamenu grobnu arhitekturu i nalaze se na jugozapadnom rubu tumula te izlaze izvan njegova nanosa (Petrinec 2005; Šućur 2015b: 155-183).
} 


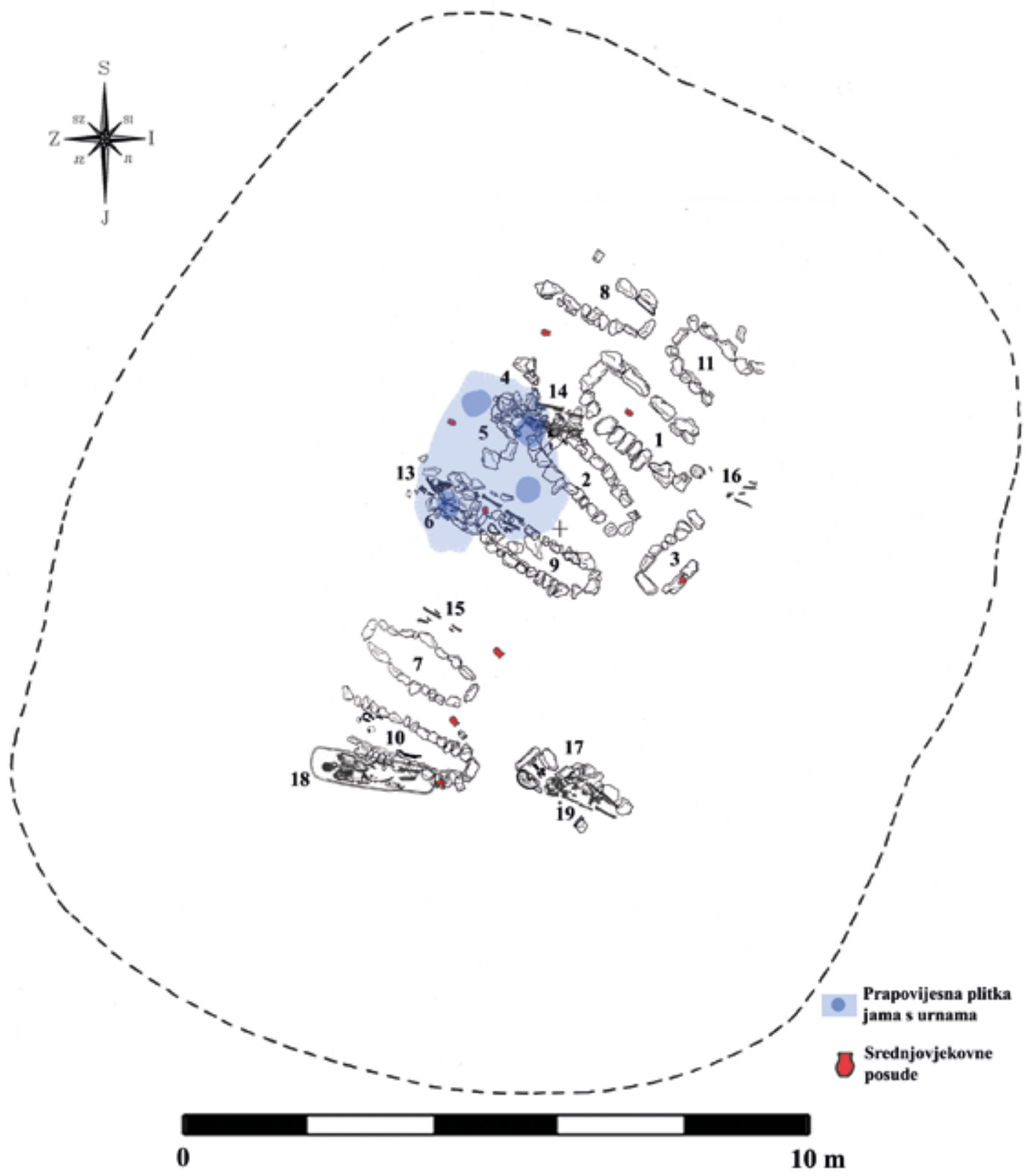

ma ovdje možemo pribrojiti i neistražene tumule s kamicima s obzirom na to da ti nadgrobni spomenici nastaju od sredine 12. st. pa do kraja 16. st., ali ih najveći broj pripada kasnom srednjem vijeku, odnosno najintenzivnije se klešu od sredine 14. st. pa do pada Bosne pod Turke 1463. godine. Kamici se često javljaju u kontekstu tumula (sl. 6). Na prostoru između Krke i Konavala zabilježeno je 38 lokaliteta gdje se kamici nalaze u kontekstu jednog ili više tumula (Bešlagić 2004: 164-176; Tomasović et al. 2008: 58-117; Šućur 2015a: 187-190). 


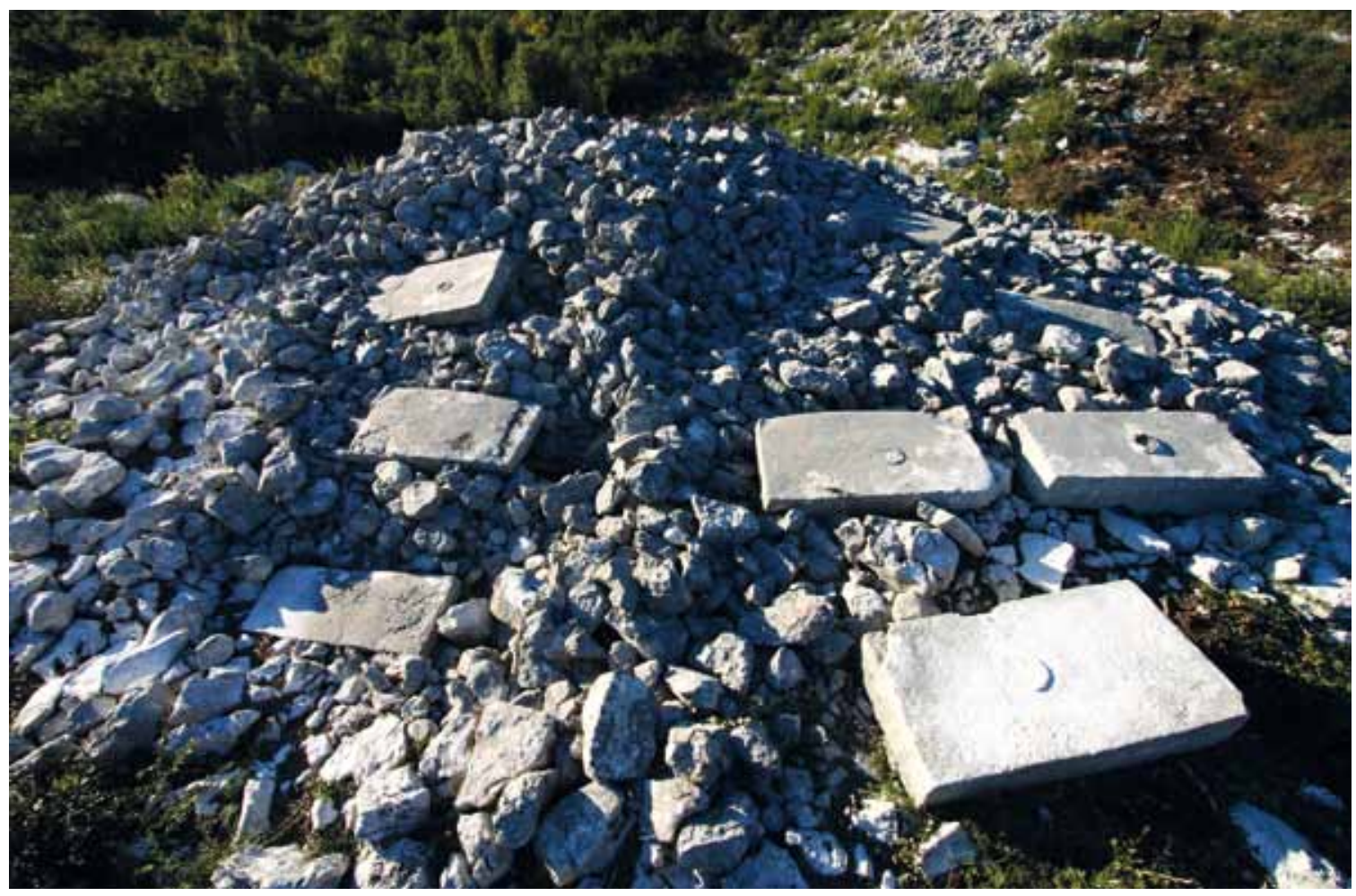

Svi potpuno istraženi tumuli s kamicima nalaze se u Plini, brdskom prostoru u zaleđu Ploča, no ovdje ću izdvojiti već spomenuti lokalitet Crljivica u Cisti Velikoj na zapadu Imotske krajine. Tu se na tri tumula i oko njih nalazi oko 90-ak kamika različitih oblika (Tomasović et al. 2008: 85). Dio lokaliteta na Velikoj Crljivici istražen je u zaštitnim arheološkim istraživanjima 2004. godine. Istražen je prostor sjeverno od ceste koja je već ranije uništila veći dio jednog tumula, a otkrivena su 24 groba, koja se razlikuju arhitekturom, ali i stratigrafskim položajem. Dio grobova bio je građen kamenim pločama, a datiran je nalazima novca u isto vrijeme kao i kamici - 14. i 15. st., s tim kako neki sigurno pripadaju ranome novom vijeku jer su u njima nađeni probušena turska akča i željezni potplati cipela. Šest grobova nema kamenu grobnu arhitekturu, u njima nije bilo nalaza te je pokopan po jedan pokojnik, a njihov stratigrafski položaj, $\mathrm{u}$ odnosu na grobove s kamenom arhitekturom koji ih dijelom preslojavaju, pokazuje kako su stariji (Gudelj 2005: 196-198). Nedostatak nalaza i radiokarbonskih analiza otežavaju datiranje starijeg sloja. Nepostojanje arhitekture i ukop po jednog pokojnika pokazuju sličnost s ranosrednjovjekovnim grobovima, ali prekrižene ruke ukazuju na kasnije vrijeme te su analogni trima grobovima s tjemena tumula Nin - Materiza (Belošević 1973: 221). Dva slična horizonta naknadnih ukopa javljaju se na tumulu 1 u Kozici gdje je stariji bez arhitekture datiran u rani srednji vijek na osnovi radiokarbonske analize groba K4 - na kraj 10. i prvu pol. 11. st. (Šućur 2015a: 112). Ovi tumuli svjedoče o višestrukim horizontima ukapanja u tumule bez direktnog kontinuiteta - prapovijest / rani srednji vijek / kasni srednji vijek.

Grobovi kasnoga srednjeg vijeka posebno su zanimljivi u kontekstu teme recikliranja jer su u usporedbi s grobovima ranijih razdoblja češće korišteni za višekratne ukope (sl. 7). Kod ranosrednjovjekovnih grobova s više pokojnika uglavnom se radi o ukopu djece ili jednog odraslog pokojnika s djecom (Šućur 2015a: 173-174), dok se kod kasnosrednjovjekovnih javljaju razne kombinacije odraslih pokojnika i djece - dva, tri, četiri i pet pokojnika (Šućur 2015a: 203). 
Slično se grobovi koriste i u ranome novom vijeku, što nije neobično jer se radi o kontinuitetu iz kasnoga srednjeg vijeka. Dio grobova u tumulima moguće je zbog nalaza ili radiokarbonskih analiza sa sigurnošću datirati u kasni srednji i rani novi vijek. Tom prijelaznom periodu, odnosno 15. i 16. st., pripadaju grobovi s tumula Veliki Vanik (1460.-1660.), Mišja Draga - Tumul 6 (15.-17. st.) i Put uz Vrbicu - Tumul 11 (15.-17. st.). Ranome novom vijeku vjerojatno pripadaju i grobovi s tumula Bristivica - Gomila na Šupljaku, te najveći dio grobova s lokaliteta Koprivno - Kod križa, iako se s ukapanjem počelo u kasnome srednjem vijeku.

Možda najzanimljiviji lokalitet predstavlja Put uz Vrbicu - Tumul 11 gdje je ukapanje započelo još u kasnome srednjem vijeku o čemu svjedoče kamici. Jedan od njih pronađen je naopako prevrnut ispod groba 3, što svjedoči o otvaranju grobova i ponovnom korištenju. Upravo u tom grobu, gdje su pronađeni ostaci najmanje triju odraslih osoba, pronađen je i dubrovački dinar kovan najvjerojatnije 1373.-1438. godine koji potvrđuje stariji horizont (Šućur 2015a: 293, kat. jed. 61.1). Svjedočanstvo novoga, ranonovovjekovnog horizonta primjeri su novca iz groba 6 - osmanska akča kovana u Mudavi 1560.-1566. godine i dubrovački dinar kovan 1617.-1621. godine (Šućur 2015a: 293, kat. jed. 61.3, 61.4).

Grobovi kasnoga novog vijeka zabilježeni su samo na lokalitetu Granica - Tumul 2. Naknadni ukopi na tom mjestu javljaju se još u 15. st. o čemu svjedoče kamici, a pojedini kasnosrednjovjekovni grobovi koriste se i u novom vijeku, kada se nekropola širi sjeverno od tumula. S obzirom na nalaze svetačkih medaljica i caravaca križa te radiokarbonsku analizu grobovi se mogu datirati u kraj 17. te 18. i 19. st. Posebno su zanimljivi osteološki ostaci označeni kao grob 22 (sl. 8). Radi se o koncentraciji dugih kostiju, orijentiranih istok - zapad, paralelno složenih na hrpu, bez tragova arhitekture, što najvjerojatnije govori kako je riječ o kostima koje su izbačene iz jednog od okolnih grobova prigodom ukopa novog pokojnika i nisu nikad vraćene u grob (Šućur 2015a: 241-249).

Najmlađi ukop zabilježen je u tumul sv. Grgur kod Nina. Pokojnik u grobu 2 ležao je na trbuhu, u smjeru istok - zapad s glavom na istoku. Obje su mu noge savijene u koljenu, kao i ruke u laktu od kojih je lijeva ispod ostatka kostura. S obzirom na položaj pokojnika i činjenicu kako je 1943. godine na vrhu tumula izgrađeno mitraljesko gnijezdo pokojnik je vjerojatno poginuo tijekom borbi u Drugome svjetskom ratu te je samo prekriven zemljom (Šućur 2015b: 29).

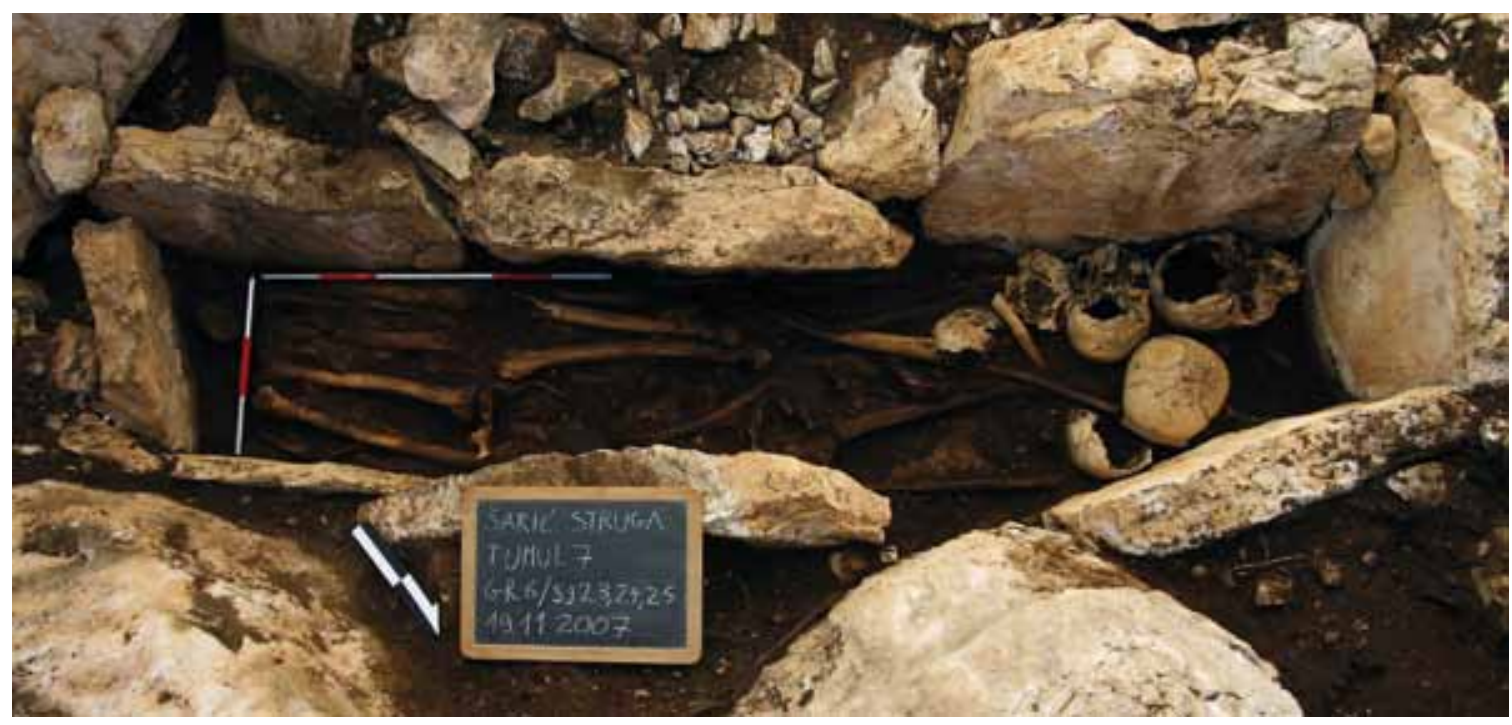

SI. 7: Grob 6 na tumulu 6 na vrhu Mišje drage u kojem su očuvani osteološki ostaci pet pokojnika (fotografirao: J. Šućur 2007.). 

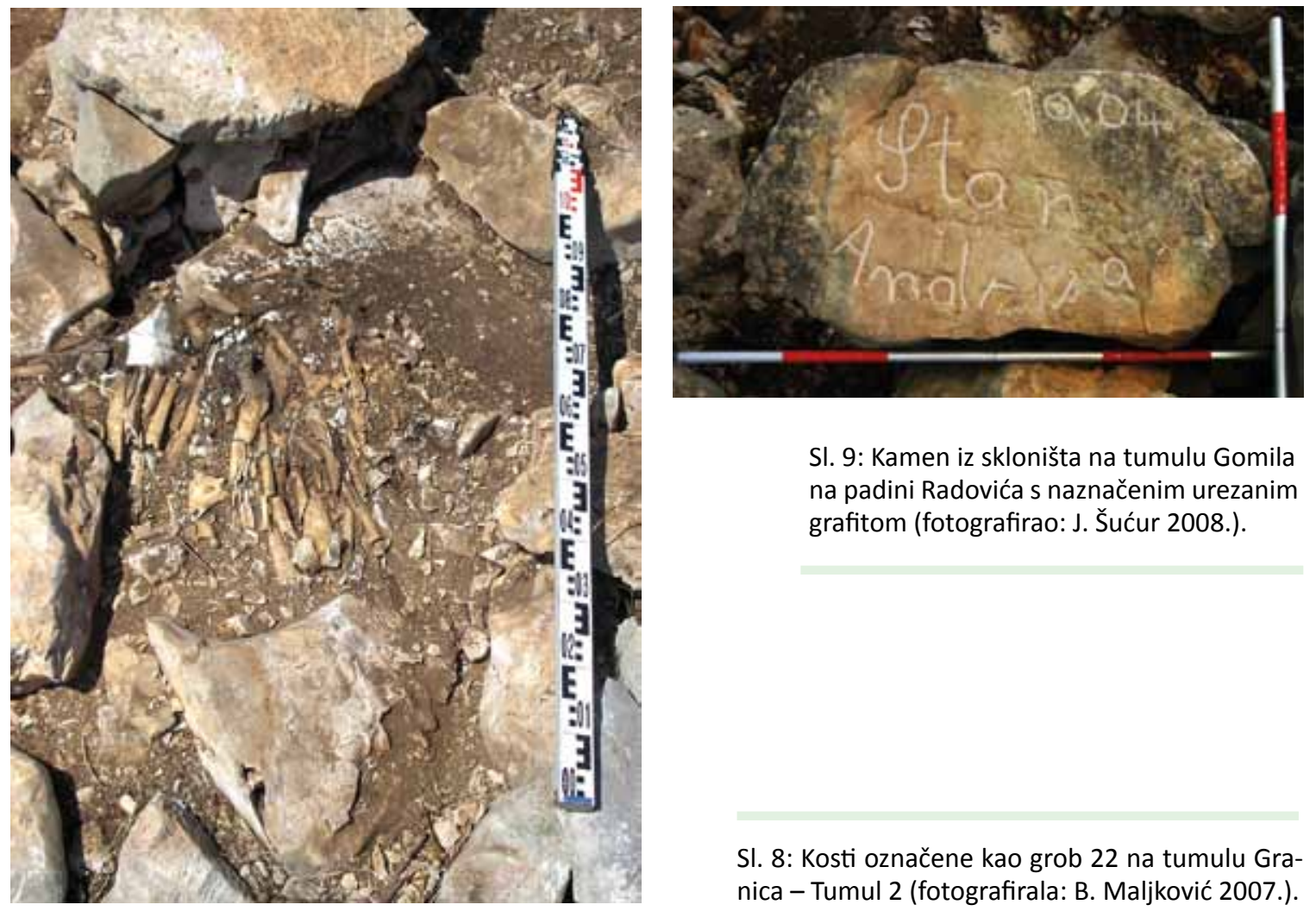

SI. 9: Kamen iz skloništa na tumulu Gomila na padini Radovića s naznačenim urezanim grafitom (fotografirao: J. Šućur 2008.).

SI. 8: Kosti označene kao grob 22 na tumulu Granica - Tumul 2 (fotografirala: B. Maljković 2007.).

\section{Manifestacije drugih aktivnosti na tumulima u Dalmaciji}

Mitraljesko gnijezdo na sv. Grguru svjedoči kako su tumuli korišteni ne samo kao nekropole već i u svrhu kontrole prostora. S obzirom na njihov često dominantan položaj u prostoru to nas ne bi trebalo čuditi, a tako je do danas o čemu svjedoče rovovi i bunkeri u velikom zemljanom tumulu Zemunjača u Smilčiću u Ravnim kotarima koji su korišteni tijekom Domovinskoga rata.

Na površini tumula česti su nalazi čahura koje svjedoče o lovačkim aktivnostima, a u nanos tumula su još češće ukopana pastirska skloništa. Tumuli su korišteni i kao pudarice - osmatračnice s kojih su se čuvali plodovi u poljima. Zanimljiv je slučaj zabilježen na lokalitetu Gomila na padini Radovića (Mucić \& Kovačević 2011: 179-185). Taj veliki kameni tumul nalazi se na najisturenijem dijelu padine brda Radović, na nadmorskoj visini od $110 \mathrm{~m}$ na prostoru gdje je polje Bunina najuže te svojom pozicijom omogućuje kontrolu najvećeg dijela polja, i zapadnog dijela koji pripada selu Kokorići i istočnog koji pripada selu Kotezi. Na njegovom zapadnom dijelu zatečeno je suhozidno sklonište prilikom čije je razgradnje u donjem redu kamena pronađen natpis - krasopisom ispisana godina i ime: 1904. Stan[ković] Andrija. Tako nam je pudar koji je početkom 20. st. s ovog tumula motrio polje, čuvajući na taj način urod, ostavio trag urezan u kamenu (sl. 9).

Položaj, a posebno uočljivost tumula dovela je do toga da su oni bili važne točke orijentacije u krajoliku. Stoga se javljaju u povijesnim izvorima, a kao primjer se može izdvojiti Povaljska listina, naš najstariji spomenik pisan ćirilicom. Taj dokument popisuje posjede benediktinskog samostana sv. Ivana u Povljima s kraja 12. st. te se u njemu među brojnim topografskim podacima koji predstavljaju najstariji sloj otočne toponimije spominju na tri mjesta i tumuli, od kojih jedan ima navedeno i ime - Pribidruža gomila (Malič 1987: 15). 


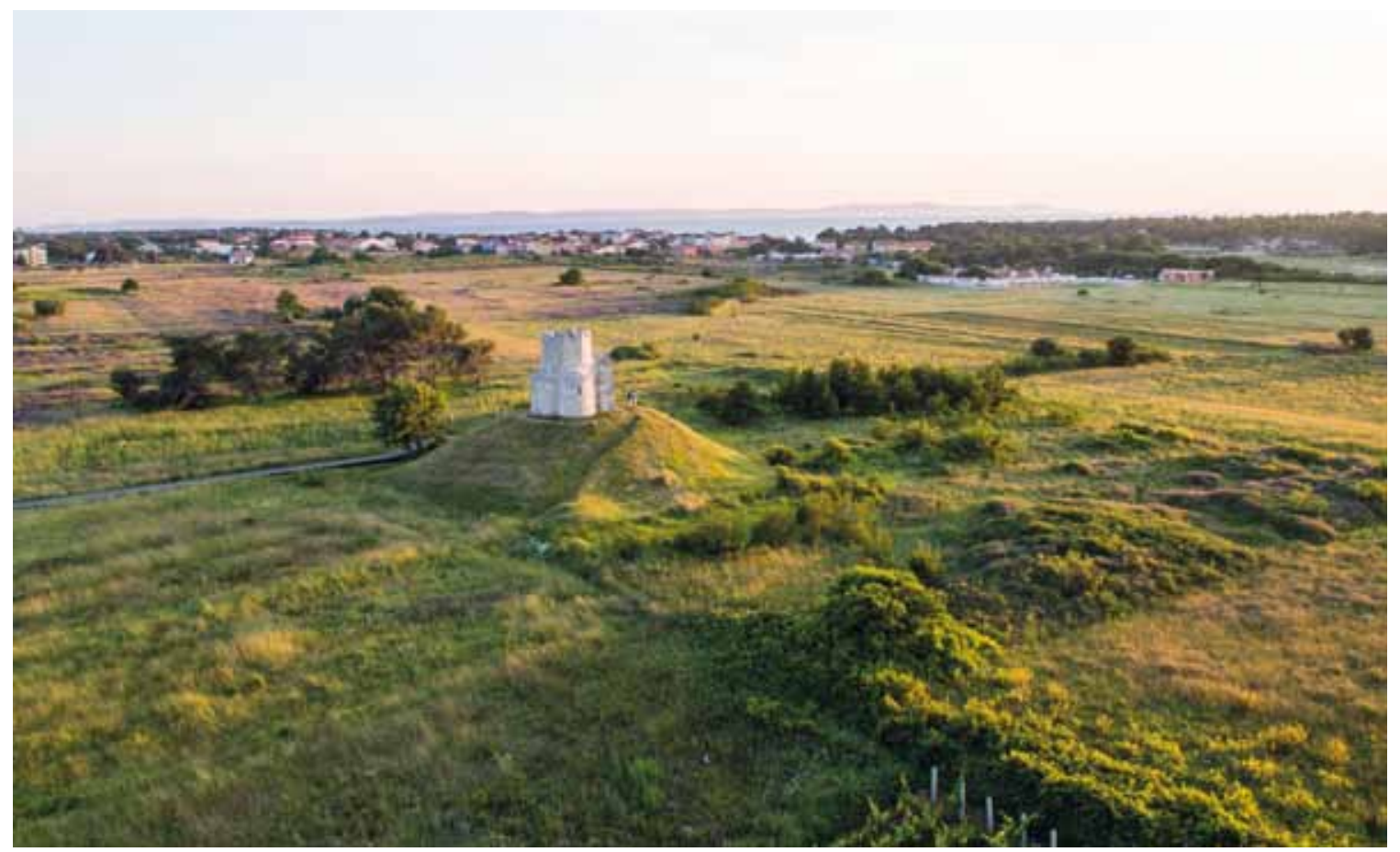

Ilustrativan primjer iz kasnijeg vremena su dokumenti o razgraničenju između Mlečana i Osmanlija u Dalmaciji iz ranoga novog vijeka gdje se granica često određuje i tumulima (Anzulović 1998). U sukcesivnom mijenjanju granične crte u Dalmaciji od 16. do 18. st. dolazilo je i do podizanja novih tumula pa je bez arheoloških istraživanja i/ili reambulacije terena teško detektirati kada su se u razgraničenju koristili već postojeći tumuli, a kada su podizani novi (Milošević 1995).

Zanimljiva je i skupina zemljanih tumula u sjevernoj Dalmaciji na kojima su podignute crkve. Uzdignuti položaj, a vjerojatno i svijest o kultnom karakteru tumula odigrali su važnu ulogu pri podizanju tih zdanja. Nijedan od tih tumula nije u potpunosti istražen, a najistraženiji je tumul sv. Grgur kod Nina. Tumul je istraživan u dva navrata: 1929.-1930. i 2008. godine, a u oba istraživanja nije istražen sjeverozapadni dio. Na tumulu su dokumentirani ostaci jednobrodne crkve s polukružnom apsidom posvećene papi Grguru te ukupno osam grobova (Predovan 2008; Radović 2009; Šućur 2015a: 70-71). ${ }^{5}$

Najpoznatija ovakva crkva je ona sv. Nikole u Prahuljama oko 1,5 km južno od ninskog otočića. Nad romaničkom crkvom križne osnove podignuta je u 15. st., nakon prvih osmanskih provala, kula osmatračnica i tako je nastala građevina koja je postala jedan od simbola Nina (sl. 10). Prilikom posljednjih konzervatorskih zahvata 1997.-1999. godine naišlo se unutar crkve na tjemenu tumula na grob, ali više od toga nije poznato (Vežić 2011: 51-53).

U blizini, u Privlaci se nalazi još jedna crkva na manjem tumulu - sv. Vid. Na širem prostoru oko crkve susreću se grobovi što se vezuje uz činjenicu kako je ova crkva bila župna crkva sela Kupara (Brusić 1973: 434-435).

\footnotetext{
${ }^{5}$ Grob 4 predstavlja ostatke kamene arhitekture prapovijesnog groba, dok je grob 3 već spomenuti „ukop“ iz vremena Drugoga svjetskog rata.
} 
Brojni tumuli s ukopima od kasne antike do novog vijeka rječiti su svjedok kako tumuli nisu samo prapovijesni nadgrobni spomenici. Ponovno korištenje prapovijesnih grobova u u srednjem i novome vijeku kada je njihova arhitektura preoblikovana kako bi omogućili drukčiji ritus ukopa svjedoči o tome kako su ljudi pri naknadnim ukopima svakako bili svjesni njihova sepulkralnog karaktera. Na tumulu 1 u Kozici to se dogodilo u kasnome srednjem vijeku, a na tumulu 11 u Vrbici u ranom novom vijeku (sl. 11).

Najbrojniji su grobovi iz ranoga i kasnoga srednjeg vijeka dok se mali broj ukopa u tumule u razvijenom srednjem vijeku može objasniti na isti način koji objašnjava smanjenje broja uobičajenih nekropola - ograničenjem ukapanja na župna groblja od 11. st. (Burić 2001: 245). Grobovi kasne antike su malobrojni, a to je vrijeme kada funkcioniraju brojne starokršćanske nekropole koje se prostorno vezuju za ranija mjesta ukopa, a ponekad se na njima grade i cemeterijalne bazilike.

Malobrojni su i ukopi u tumule nakon ranoga novog vijeka. Za vrijeme Josipa II. (1780.-90.), a zatim i francuske uprave u Ilirskim pokrajinama (1806.-1813.) dolazi do promjena kod ukapanja - zabranjuje se ukapanje u crkvama, ukidaju se crkvena groblja i formiraju velika gradska groblja. Ove promjene dovode do toga da su ukopi izvan sekularnog gradskog i crkvenog seoskog groblja iznimno rijetki.

O poštovanju tumula kao kultnih mjesta svjedoče i primjeri crkava podignutih na njima, a svoje su značenje u krajoliku posvjedočili i drugim funkcijama - kao međaši, osmatračnice, orijentiri...

Tumuli se zbog svega navedenog ne mogu smatrati samo prapovijesnim spomenicima već su neodvojiv dio krajolika od samog nastanka do danas i kao takvi privlače ljudsku pažnju o čemu svjedoče brojni tragovi aktivnosti - kako duhovnih tako i profanih.

SI. 11: Grob 1 na tumulu 11 u Vrbici - ranonovovjekovni ukop koji je jednim dijelom iskoristio prapovijesnu kamenu grobnu škrinju (fotografirala: S. Bogdanović 2007.).

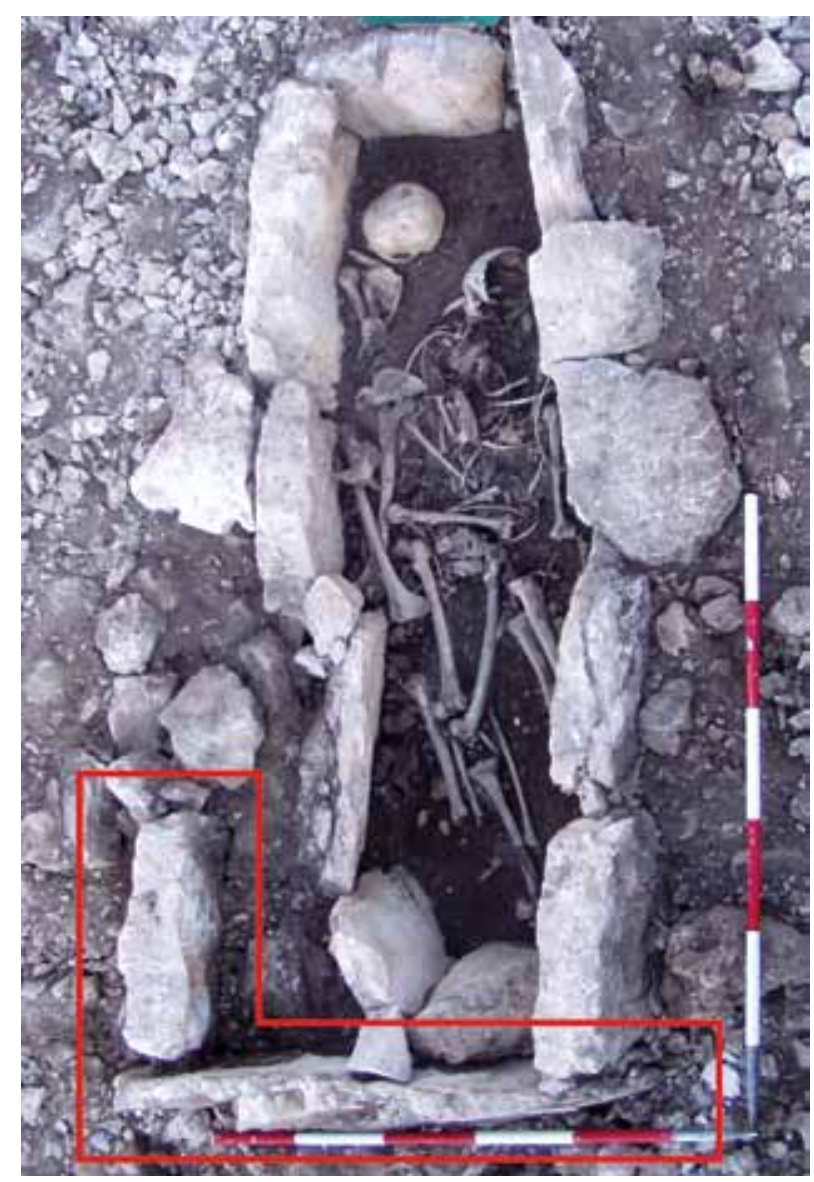


Anzulović, I. 1998. Razgraničenje između mletačke i turske vlasti na zadarskom prostoru 1576. godine, nakon Ciparskog rata. Zadarska smotra God. XLVII, br. 1-3. Matica hrvatska. Zadar. 53150.

Amore, M. G. 2009. The Complex of Tumuli 9, 10, and 11 in the Necropolis of Apollonia. New Light on the History of Colony, L'Illyrie méridionale et l'Épir dans l'Antiquité - V. Actes du V. colloque international de Grenoble (8-11 octobre 2008), Volume I. De Boccard. Paris. 181-188.

Batović, Š. 1963. Razvoj istraživanja prapovijesti u Dalmaciji. Radovi. Filozofski fakultet - Zadar 2, Razdio historije, arheologije i historije umjetnosti (1) 1960/1961. Filozofski fakultet Zadar. Zadar. 37-73.

Belošević, J. 1968. Ranosrednjovjekovna nekropola u selu Kašiću kraj Zadra. Diadora 4. Arheološki muzej. Zadar. 221-246.

Belošević, J. 1973. Starohrvatska nekropola uz humak „Materiza“ kod Nina. Diadora 6. Arheološki muzej. Zadar. 221-244.

Belošević, J. 1980. Materijalna kultura Hrvata od VII do IX stoljeća. Slobodna naklada Liber. Zagreb.

Bešlagić, Š. 2004. Leksikon stećaka. Svjetlost. Sarajevo.

Boglić, G. 1873. Studi storici sull'isola de Lesina Fascicolo I. Tip. di Giovanni Woditzka. Zadar.

Brusić, Z. 1973. Privlaka kod Zadra, arheološko-topografski podaci. Radovi Instituta Jugoslavenske akademije znanosti i umjetnosti u Zadru XX. Institut Jugoslavenske akademije znanosti i umjetnosti u Zadru. Zadar. 419-446.

Bucchich, G. 1885. - Ricerche preistoriche sull>Isola di Lesina. Bullettino di archeologia e storia Dalmata 3. Arheološki muzej Split. Split. 1-11.

Burić, T. 2001. Putalj u srednjem vijeku. Sv. Juraj od Putalja. Muzej hrvatskih arheoloških spomenika. Split. 151-322.

Carver, M. 1998. Überlegungen zur Bedeutung angelsächsischer Grabhügel. Studien zur Archäologie des Ostseeraumes von der Eisenzeit bis zum Mittelalter. Festschrift für Michael Müller-Wille. Wachholtz. Neumünster. 259-268.

Dragun, V. \& Ujević, B. 2014. Legende imotskog krša. Agencija za odgoj i obrazovanje, Škola za dizajn, grafiku i održivu gradnju. Zagreb - Split.

Fabijanić, T. 2008. Ranokršćanske pticolike fibule u svjetlu neobjavljenih nalaza iz Danila i Podumaca. Prilozi Instituta za arheologiju u Zagrebu 24. Institut za arheologiju. Zagreb. 263-271. Gudelj, LJ. 2005. Velika Crljivica i groblje kod crkve sv. Jakova. Zaštitna istraživanja u općini Cisti Provo 2004.-2005. godine. Starohrvatska prosvjeta III. ser. 32. Muzej hrvatskih arheoloških spomenika. Split. 195-215.

Gusar, K. \& Vujević, D. 2012. Matakova glavica. Tumuli iz Krneze i Podvršja kod Zadra. Sveučilište u Zadru. Zadar. 151-173.

Hejhal, P. \& Lutovský, M. 2012. In agris sive in silvis... Secondary medieval burials in ancient barrows in Bohemia. Rome. Constantinople and newly-converted Europe: Archaeological and Historical Evidence. Geisteswissenschaftliches Zentrum Geschichte und Kultur Ostmitteleuropas, Instytut Archeologii i Etnologii PAN. Instytut Archeologii Uniwersytetu Rzeszowskiego. Kraków - Leipzig - Rzeszów - Warszawa. 517-524.

Jutronić, A. 1955. Vicko Prodić i njegova „Cronica dell'isola della Brazza“. Starine Knjiga 45. JAZU. Zagreb. 331-388.

Kužić, K. 2001. Zašto bi trebalo terminom „kamik” zamijeniti termin „stećak”?. Povijesni prilozi 20. Hrvatski institut za povijest. Zagreb. 259-273. 
Lutovský, M. 1989. Územní rozšíření slovanských mohyl ve Střední Evropé. K problému mohylových oblastí. Archeologické rozhledy XLI (1). Archeologický ústav AV ČR. Praha. 59-74.

Lutovský, M. 1990. K některým problémům vypodvídacích schopností rané středověkých mohyl. Archeologické rozhledy XLII (4). Archeologický ústav AV ČR. Praha. 353-361.

Lutovský, M. 1996. Between Sutton Hoo and Chernaya Mogila: barrows in eastern and western early medieval Europe. Antiquity 70 (269). Cambridge University Press. Durham. 671-676.

Malič, D. 1987. Povaljska listina. Latinička transliteracija teksta. Obljetnica Povaljske listine $i$ praga 1184-1984. = Brački zbornik XV. SIZ za kulturu Općine Brač. Supetar. 11-16.

Marović, I. 1963. Iskopavanja kamenih gomila oko vrela rijeke Cetine god. 1953, 1954. i 1958. Vjesnik za arheologiju i historiju dalmatinsku LXI/1959. Arheološki muzej Split. Split. 5-80.

Měřínský, Z. 2009. České země od př́chodu Slovanů po Velkou Moravu I. Nakladatelství Libri. Praha.

Meurkens, L. 2010. The late medieval/Early Modern reuse of prehistoric barrows as execution sites in the southern part of the Netherlands. Journal of Archaeology in the Low Countries 2 (2). Amsterdam University Press. Amsterdam. 5-29.

Milošević, A. 1995. Mletačka kartografija kao izvor za arheološku topografiju Dalmacije. Histria antiqua 1. Međunarodni istraživački centar za arheologiju. Pula. 105-108.

Mucić, K. \& Kovačević, N. 2011. Doprinosi poznavanju povijesti Vrgoračke krajine na osnovi rezultata novijih arheoloških istraživanja. Arheološka istraživanja na trasi autoceste u Zabiokovlju i Plini. Gradski muzej Makarska. Makarska. 125-212.

Niederle, L. 1954. Slovenske starine. Matica srpska. Novi Sad.

Novak, G. 1924. Hvar. Jugoslovenska štampa. Beograd.

Petrić, N. 1975. Arheološka istraživanja otoka Hvara. Hvarski zbornik 3. Samoupravna interesna zajednica za kulturu općine Hvar. Split. 243-292.

Petrić, N. 1977. Grgur Bučić i arheološka istraživanja na Hvaru u 19. stoljeću. Hvar u prirodnim znanostima: zbornik simpozija. JAZU. Zagreb. 221-233.

Petrinec, M. 2005. Ranosrednjovjekovno groblje na položaju Livade u Konjskom polju. Starohrvatska prosvjeta III. ser. 32. Muzej hrvatskih arheoloških spomenika. Split. 21-52.

Petrinec, M. 2009. Groblja od 8. do 11. stoljeća na području ranosrednjovjekovne hrvatske države. Muzej hrvatskih arheoloških spomenika. Split.

Predovan, M. 2008. Crkva sv. Grgura pored Nina - nove spoznaje o povijesti arheoloških istraživanja. Obavijesti XXXX/1. Hrvatsko arheološko društvo. Zagreb. 106-113.

Radović, M. 2009. Nin - Sv. Grgur. Hrvatski arheološki godišnjak 5/2008. Ministarstvo kulture. Zagreb. 490-491.

Srejović, D. 1997. Tumul. U: Arheološki leksikon. (ur. D. Srejović). Savremena administracija. Beograd. 1067-1068.

Šućur, J. 2015a. Ukapanje u prapovijesnim tumulima od kasne antike do novog vijeka Sv.1. Doktorska disertacija. Sveučilište u Zadru.

Šućur, J. 2015b. Ukapanje u prapovijesnim tumulima od kasne antike do novog vijeka Sv. 2. Katalog nalazišta. Doktorska disertacija. Sveučilište u Zadru.

Tomasović, M., Perkić, D. \& Alduk, I. 2008. Topografija stećaka u Hrvatskoj. Stećci. Galerija Klovićevi dvori. Zagreb. 58-117.

Van de Noort, R. 1993. The context of Early Medieval barrows in western Europe. Antiquity 67. Cambridge University Press. Durham. 66-73. 
Veseličić, M. 2008. Сахрањивање током средњег века и новијег доба у праисторијским хумкама у чачачком крају. Зборник радова Народног музеја XXXVIII. Народни музеј. Чачак, 2008. 93-130.

Vežić, P. 2011. Dalmatinski trikonhosi. Ars Adriatica 1. Sveučilište u Zadru. Zadar. 27-66.

Vinski, Z. 1991. Razmatranja o iskopavanjima u Kninu na nalazištu Greblje. Starohrvatska prosvjeta, III. ser. 19. Muzej hrvatskih arheoloških spomenika. Split. 5-73.

Vuletić Vukasović, V. 1885a. Culturhistorische und prähistorische Miscellen von der Insel Brač (Bol) in Dalmatien. Mittheilungen der Anthropologischen Gesellschaft in Wien XV. Band (Der neuen Folge V. Band). Anthropologische Gesellschaft in Wien. Wien. [49]-[52].

Vuletić Vukasović, V. 1885b. У опће о хумкама а напосе о гомилама у Далмацији иу Херцеговини. Старинар. Српско археолошко друштво. Београд. 45-56.

Weiser, M. E. 1884. Tumuli und prähistorische Funde auf der Insel Lesina. Mittheilungen der anthropologischen Gesellschaft in Wien XIV. Band. Anthropologische Gesellschaft in Wien. Wien. [8]-[9]. 